\title{
Report of Test Excavations Along S.H. 16 in Bexar County 41BX502
}

Wayne C. Young

Follow this and additional works at: https://scholarworks.sfasu.edu/ita

Part of the American Material Culture Commons, Archaeological Anthropology Commons, Environmental Studies Commons, Other American Studies Commons, Other Arts and Humanities Commons, Other History of Art, Architecture, and Archaeology Commons, and the United States History Commons

Tell us how this article helped you.

This Article is brought to you for free and open access by the Center for Regional Heritage Research at SFA ScholarWorks. It has been accepted for inclusion in Index of Texas Archaeology: Open Access Gray Literature from the Lone Star State by an authorized editor of SFA ScholarWorks. For more information, please contact cdsscholarworks@sfasu.edu. 


\section{Report of Test Excavations Along S.H. 16 in Bexar County 41BX502}

\section{Licensing Statement}

This is a work produced for the Texas Department of Transportation (TxDOT) by the report producer. TxDOT and the report producer jointly own all rights, title, and interest in and to all intellectual property developed under TXDOT's contract with the report producer. The report may be cited and brief passages from this publication may be reproduced without permission provided that credit is given to both TxDOT and the report producer. Permission to reprint an entire chapter, section, figures or tables must be obtained in advance from either the Supervisor of the Archeological Studies Branch, Environmental Affairs Division, Texas Department of Transportation, 125 East 11th Street, Austin, Texas, 78701 or from the report producer. 
REPORT OF TEST EXCAVATIONS

ALONG S.H. 16 IN BEXAR COUNTY

41 BX 502 
INITIAL TESTING REPORT AND RECOMMENDATIONS FOR ARCHAEOLOGICAL RESOURCES ALONG PROPOSED

S.H. 16, BEXAR COUNTY TEXAS

Wayne C. Young

State Department of Highways and Public Transportation

Archaeology Section 
Initial Testing Report and Recommendations

for Archaeological Resources along Proposed

S.H. 16, Bexar County, Texas

Archaeological site $41 B \times 502$ is located in the center of San Geronimo, a hamlet in western Bexar County. The site is situated within the Texas Hill Country at an elevation approximately 1250 feet above mean sea level (384 meters). This site extends along a sloping hillside and terrace system immediately north of the juncture of Habey and San Geronimo Creeks and is cut on the west by the present route of State Highway 16. The site extends approximately 300 meters north and south along the present course of the highway and at least 300 meters east and west along Habey Creek (Figure 1). Only the western edge of the site is in the expanded right-of-way of State Highway 16.

41 BX 502 was not discovered during the cultural resource survey of the proposed route, presumably due to heavy vegetation cover. The survey personnel were not informed of the site, although it had long been known to localarrowhead collectors and pothunters. The site was brought. to the attention of the archaeological section of the Texas State Department of Highwaysand Public Transportation by Mr. Don Fry, project engineer for the Department, after construction was halted but not before the site had been heavily damaged by construction activities ancl large numbers of people began inquiring about the future of the site.

The site, 41 BX. 502, was officially recorded in October, 1978, by the A rchaeology Section of the S.D.H.P.T. The testing was conducted from October 23 to November 6, 1978, under authority of Title 36, Part 600, and the Memorandum of Understanding between the Department and the Texas Antiquities Committee. 


\section{This Page Redacted Per THC Policy}


An examination of the surface of the site and discussions with local informants indicated that the site had been greatly altered in historic periods prior to construction activities. A small cemetary was located on the site and subsequently partially removed in preperation for the expansion of the highway. A cement slab from a cafe built in the early 1930's is also present on the site along with sewage and lateral lines. Local informants told us that other structures included a small barn or shed built in the 1930's along the southern end of the site. The existence of this structure was confirmed by a large, unburned, post found in Test Unit 1. Three private driveways also crossed the site and have altered it to some extent (Figure 1).

These damages were slight compared to the construction activity prior to the reporting of the site. Large live oak trees growing in the right-of-way had been bulldozed down and pushed across the site to be burned (Figure 2). A deep drainage ditch had also been dug along the southern end of the site and spoil dirt piled to a height of three meters along the northern edge of the ditch. The entire surface was almost barren of vegetation and churned to a minimum depth of $15 \mathrm{~cm}$.

The site had also been heavily collected and pothunted. Potholes were most evident along the southern portion of the site and in the central area between the cafe slab and Backhoe Trench 4 .

Three surface concentrations of prehistoric cultural material were observed and are shown on Figure 1. Theseareas were tested with eight backhoe trenches and two test units, consisting of 2 meter squares dug in atrbitrary $10 \mathrm{~cm}$. levels to basal clays.

The concentration nearest Habey Creek was tested with Backhoe Trenches 1 and 2 and Test Unit 1 . The concentration was situated along a small knoll which was about 20 meters long in the right-of-way and extended 


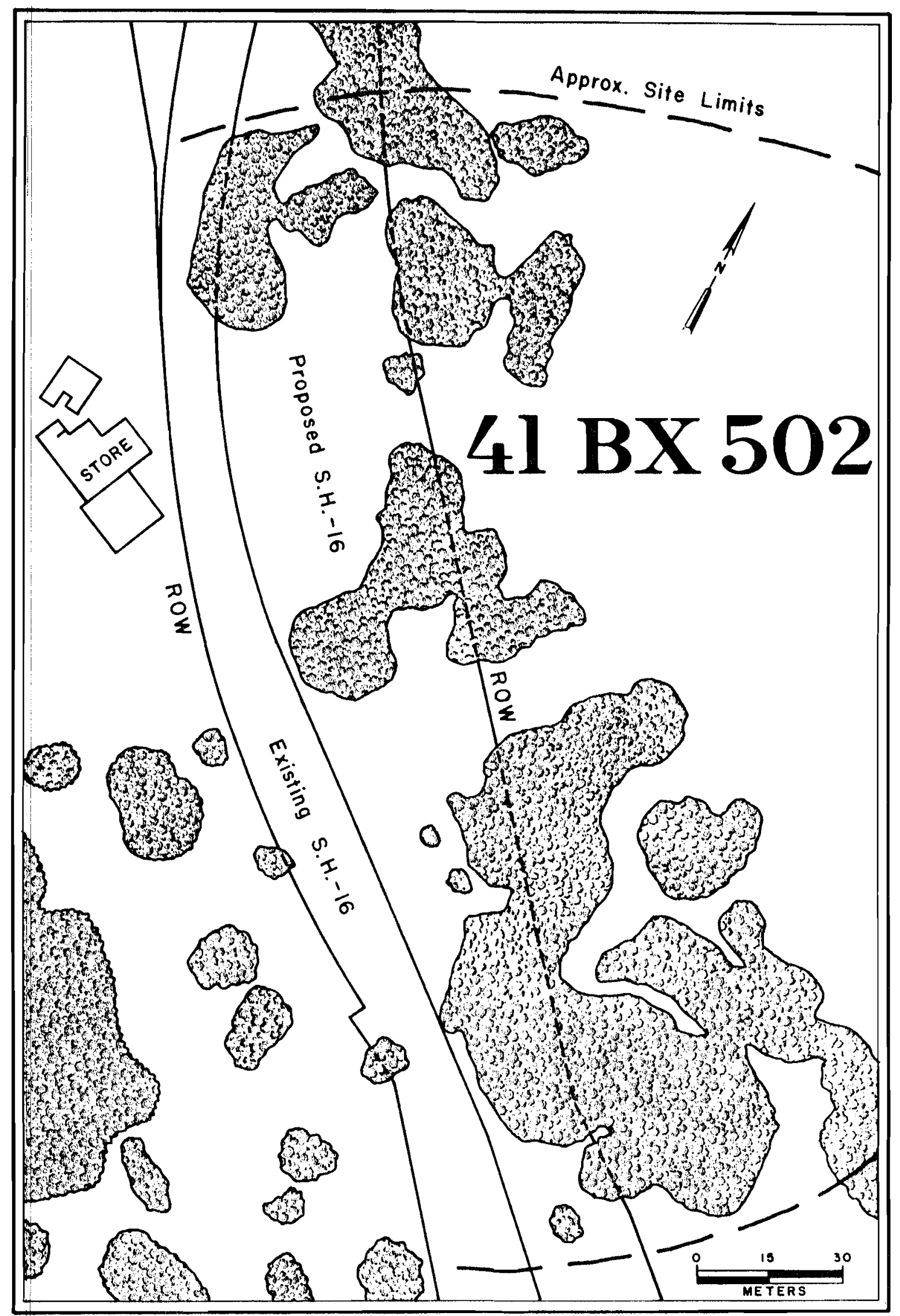

Figure 2. Pre-construction tree cover ( $41 B X$ 502) 
westwar@nto private property. A potion of this area had been graded away in the past by Mr. Hernandez, the adjacent landowner, to control erosiononto his property. Recently the urea has been scraped with a front-end loader down to basal gravels This area has also been heavily pothunted along its southeastern margin.

Soil profiles from the backhoe trenches revealed a'basic profile of a dark brown sandy loamoverlying a yellow loam. Trench I contained two gravel and caliche lense which were interpreted as preoccupation flood deposition. Allof the observable cultural material was contained within the top soil zone. A considerable amountsf disturbancewas observed in Backhoe Trench 2 (Figure 3) and in Test Unit lwhich yielded mixed prehistoric and historic materials to a depth of $50 \mathrm{~cm}$ (Figure 4). As mentioned above an unburned post was observed in Test Unit 1 extending at least to $50 \mathrm{~cm}$ below the present ground level.

A quantity of prehistoric. cultural material was recovered from this part of 41 BX 502, butwithout any valid context: due to mixing of the prehistoric and historic zones and an apparent reversal of normal sequences of diagnostic artifacts. Level 2 of Test Unit 1 produced a Fairland point, Level 3 yielded a Williams-like point, level 4 contaned an Edwards arrowpoint: and level 5 producea small biface fragment. Historic material were also found throughout the deposits (Figure 4).

The second surface concentration was scattered along a small rise in the center of the site. Thisconcentration occured in an area about 55 meters long and 20 meters wide; and contained the cafe slab and the historic cemetary. The tests in this area include Backhoe Trenches 3, 4, 5, and 6, and Test U nit 2. Each backhoe trench contiained different soil profiles and these will be discussed seperately. 

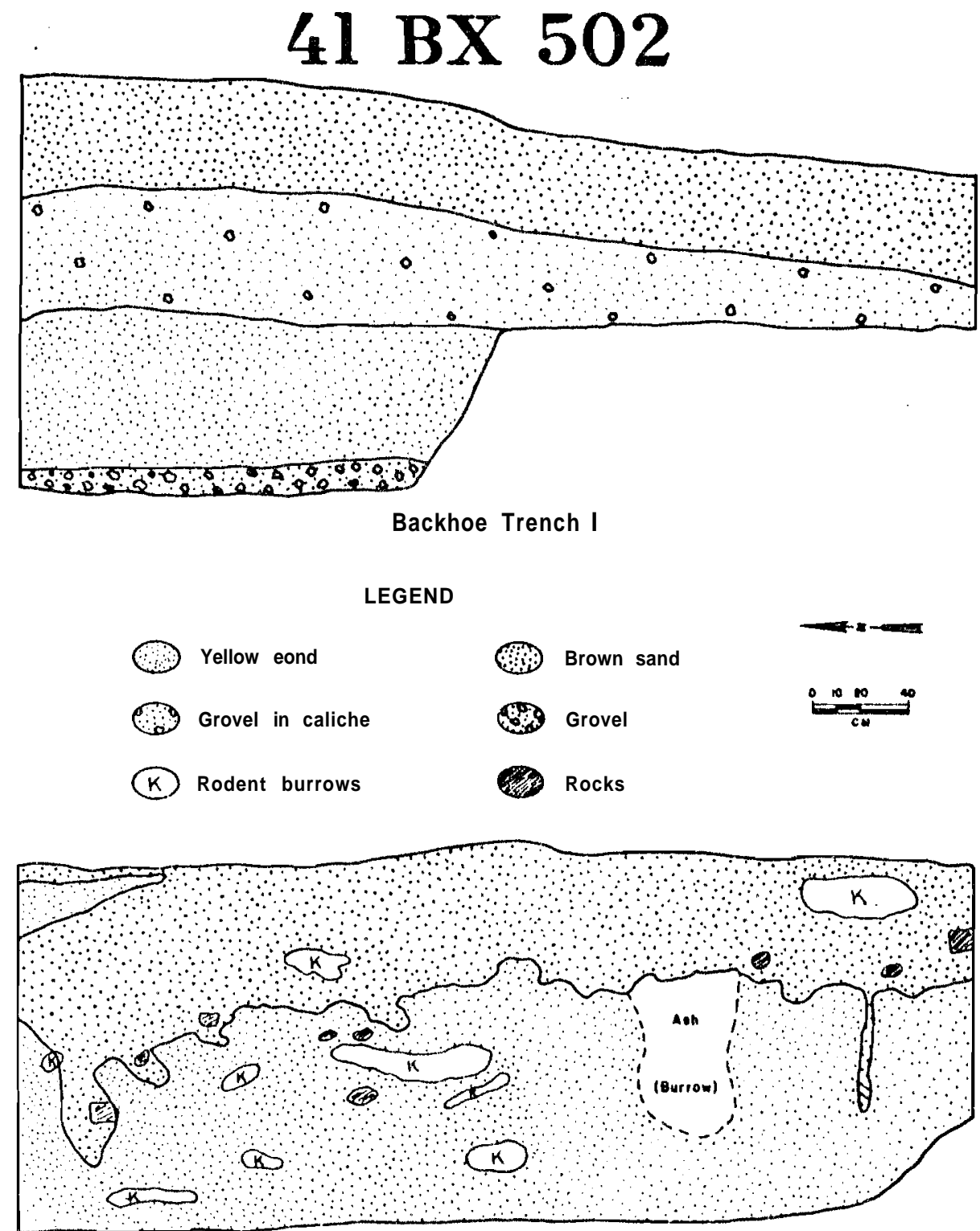

Backhoe Trench 2

Figure 3. Soil Profiles - Backhoe Trenches 1 \& 2 (41 BX 502) 


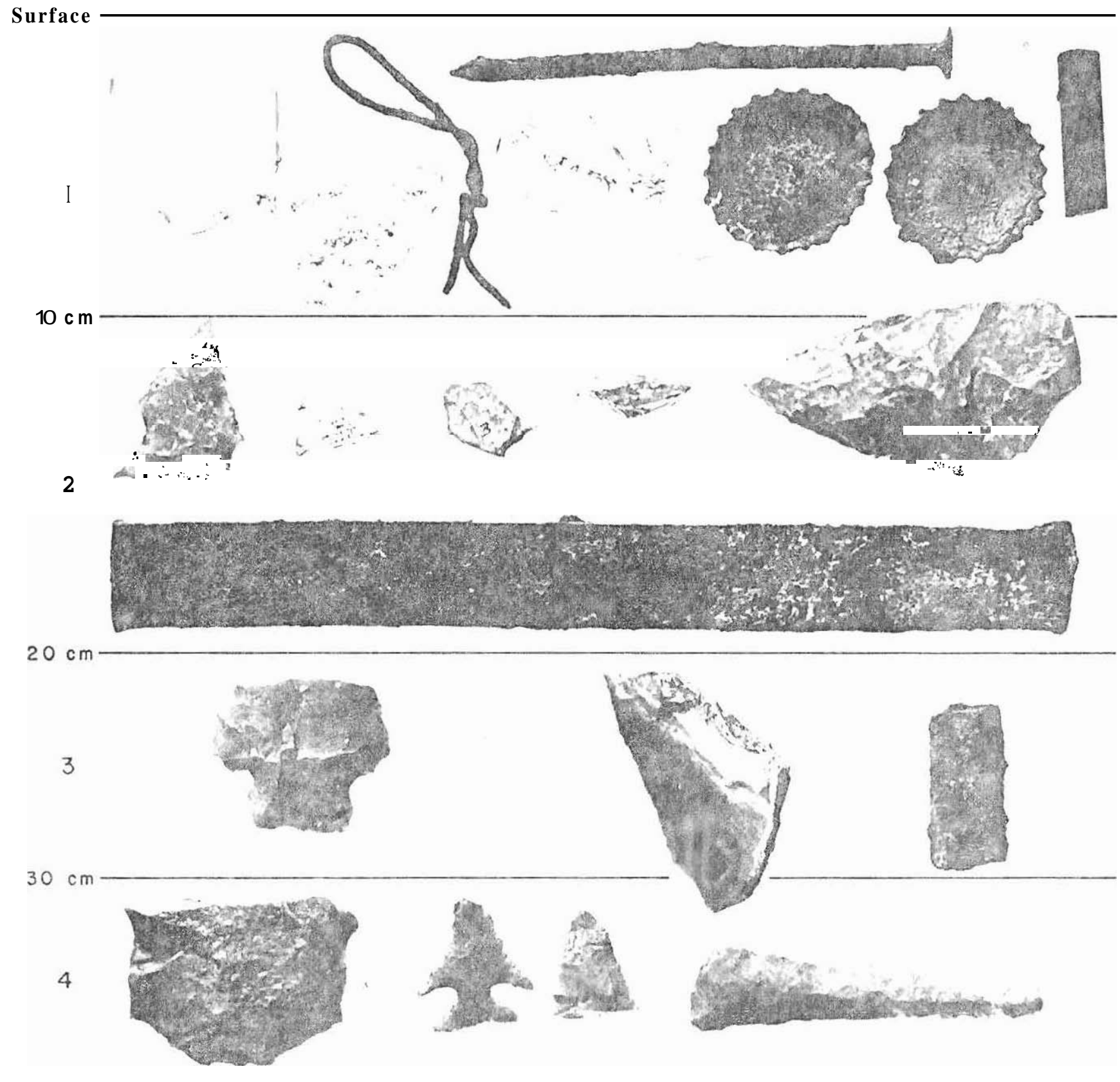

$40 \mathrm{~cm}$

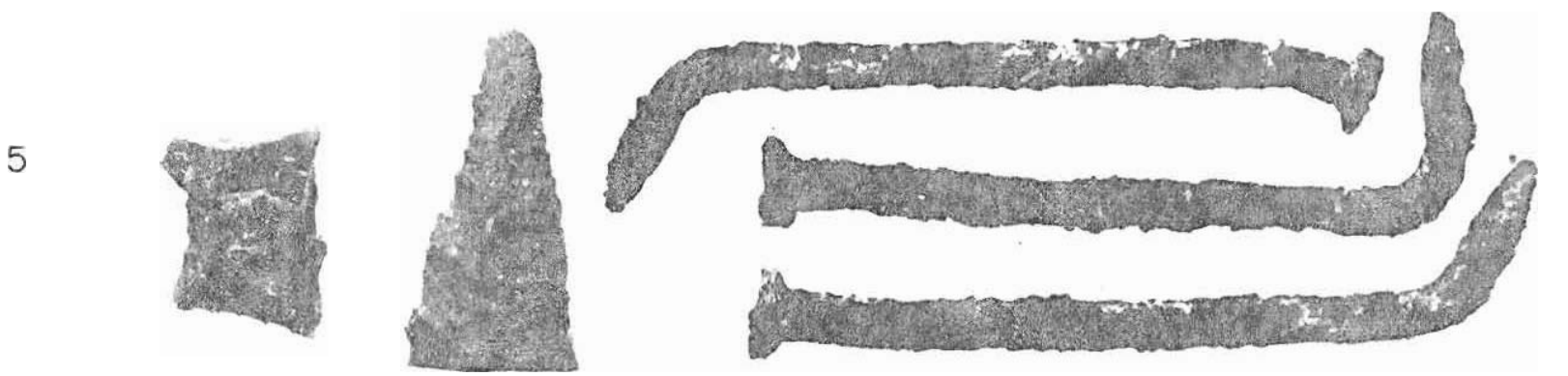

$50 \mathrm{~cm}$

Figure 4. Selected Artifacts from Test Unit 1 (41 BX 502). 
Backhoe Trench 3 was in a heavily churned area and contained a yellow clay, normally a basal material, on top of a dark brown sandy loam. This loam zone covered more yellow clay (Figure 5). No cultural materials, except a modern goat bone with a recently sawed end, were found in this trench.

Backhoe Trench 4 contained a dark brown clay loam overlying a yellow clay zone (Figure 5). Two bulldozer ruts filled with yellow clay were also visible in the dark brown clay loam. Several tombstone fragments were found in the top soil zone and in the yellow clay at depths suggesting a considerable amount of disturbance. A historic burial shaft extending 1.7 meters below the present ground level was also observed. The soil within this feature is well compacted and thought to indicate that the burial had not been removed. No prehistoric cultural materials were recovered from this trench.

Backhoe Trench 5 contained an extensive lens of crushed grovels on top of the dark brown clay loam. The lowest soil zone observed was a yellow clay (Figure 5). The gravel lens is thought to be a parking area associated with the cafe. A sewer pipe was also discovered in this trench nearthe bottom of the loam zone along with a quantity of metal fragments. No prehistoric materials were recovered.

Backhoe Trench 6 revealed a top soil zone of tan sandy clay overlying a lens of asphalt and a yellow clay (Figure 5). No prehistoric cultural materials were recovered from this unit. The asphalt is thought to represent a drive or parking area associated with the adjacent cafe foundation and again indicates heavy disturbance in the area. Portions of the cafe slab was also covered by as much as $30 \mathrm{~cm}$ of soil.

Test Unit 2 was excavated to a depth of $60 \mathrm{~cm}$ and contained mixed prehistoric and late historic materials to $50 \mathrm{~cm}$ (Figure 6). The lowest 


\section{$41 \mathrm{BX} 502$}

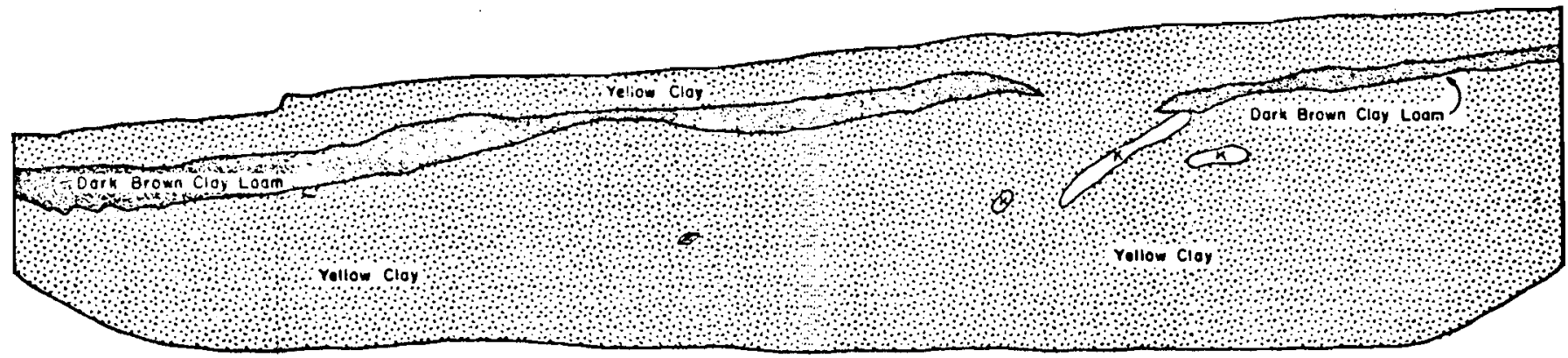

Backhoe Trench 3

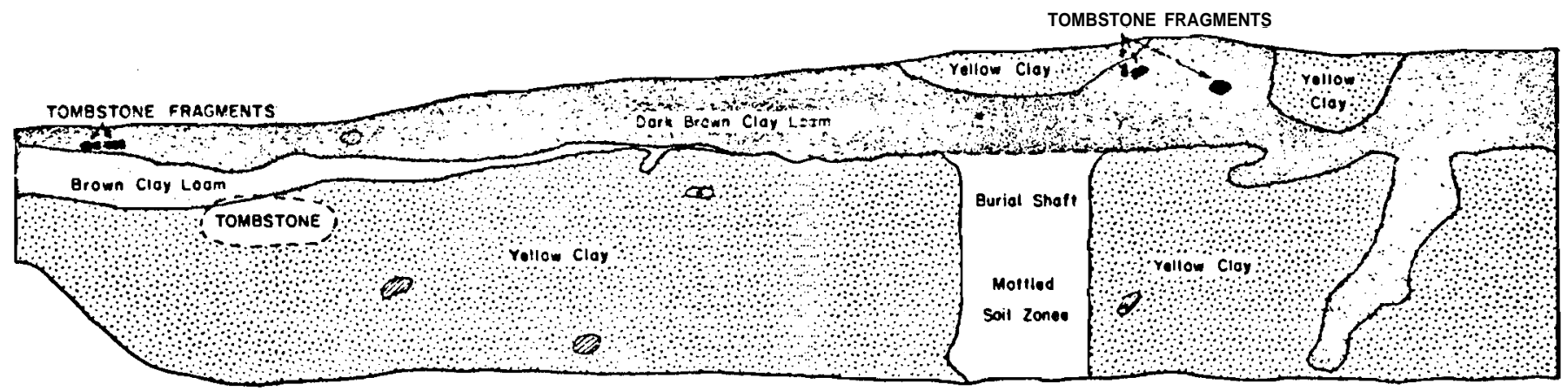

Backnoe Trengh 4

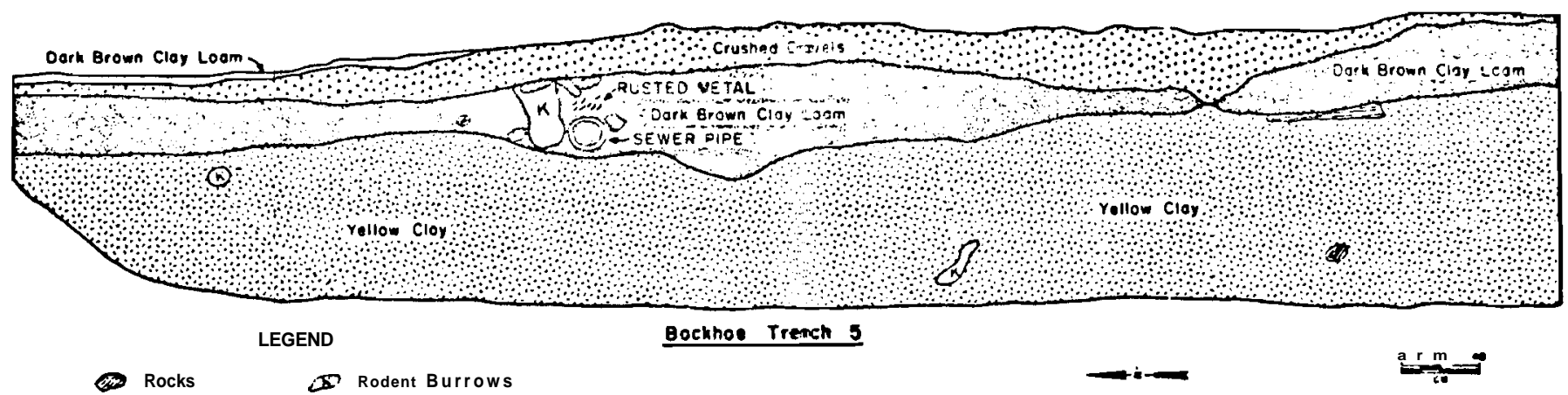

Figure 5. Soil Profiles fromBackhoe Trenches 3, 4 and 5 (41 BX 502) 


$1 \quad \begin{gathered}48 \times 502 \\ 2\end{gathered}$

$10 \mathrm{~cm}$
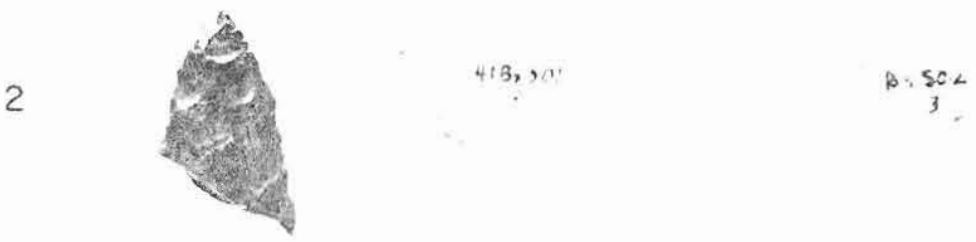

$20 \mathrm{~cm}$

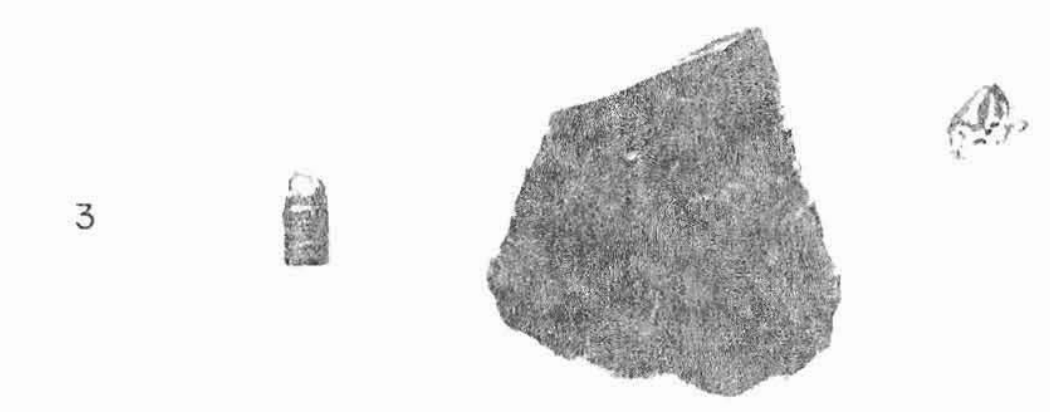

$30 \mathrm{~cm}$
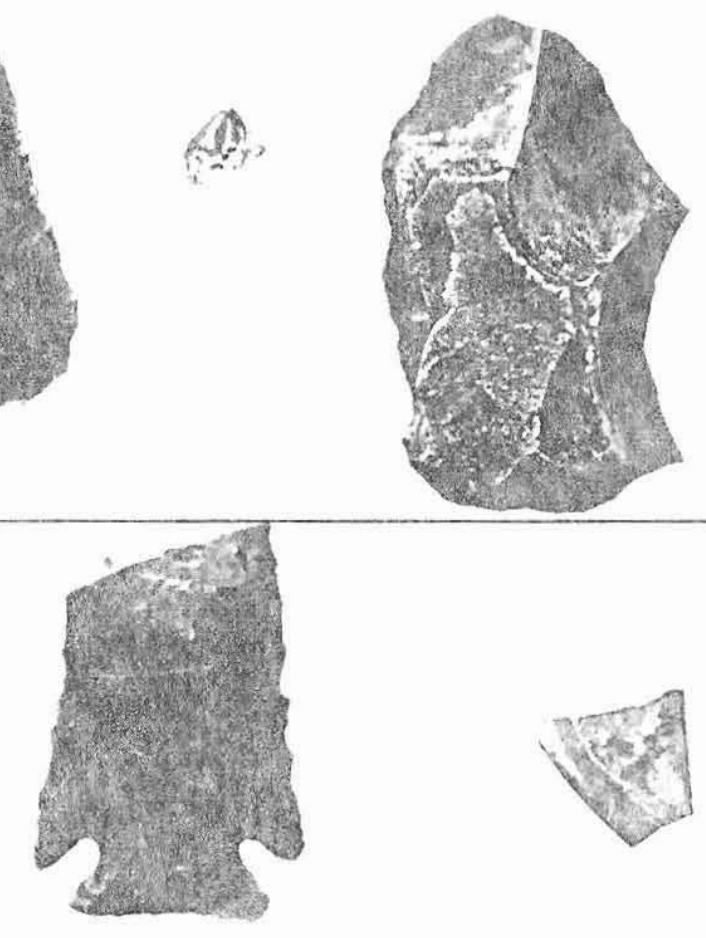

4

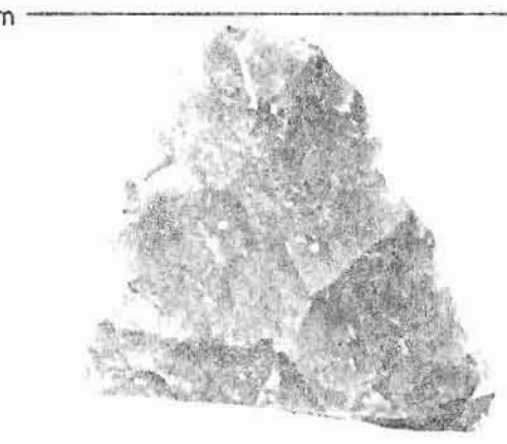

$40 \mathrm{~cm}$

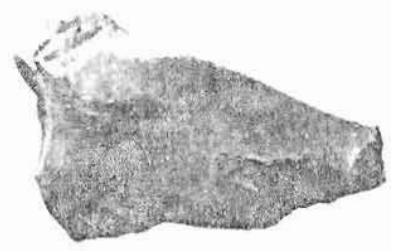

$50 \mathrm{~cm}$

Figure 6. Selected Artifacts from Test Unit 2 (41 BX 502). 
level, 50 to $60 \mathrm{~cm}$, penetrated the yellow clay zone and contained only 7 flakes

Backhoe Trench 7 was excavated into an area of darker soil in the north-central part of the site. This unit revealed a black clay overlying a greenish clay (Figure 7). Numerous roots were observed but cultural materials were absent. This area is thought to be darker in color due to greater soil moisture retention and to deposition from the top of the hill into this area.

The last concentration of surface cultural debris was on top of the hillside on the northwestern portion of $41 \mathrm{BX} 502$. This area was roughly 10 meters square. Backhoe Trench 8 was dug into this area and revealed a thin, dark brown, clay loam overlying a reddish, gravelly, loam and bedrbck (Figure 7). No cultural materials were recovered in this trench, although a Bulverde point was found in the vicinity on the surface.

The "diagnostic" artifacts recovered from the surface and the excavations appear to indicate that 41 BX 502 was a multicomponent site ranging from Middle Archaic into the Late Prehistoric period.

Artifacts found on the surface include a Bulverde, a Frio, a Pedernales, a $\underline{\text { Marcos, }}$ and a Tortugas type dart point (Figure 8). Subsurface artifacts include a Fairland, an Edwards, and a Marcos type projectile point. These specimens are normally presumed to be temporally distinct.

41 B X 502 appears to be totally disturbed by early land use and more recently by heavy construction equipment. The cultural deposits have been thoroughly mixed. These disturbances have ruined the integrity of the site and destroyed its significance in Texas prehistory.

Further archaeological mitigation is not warranted on 41 BX 502 due to the disturbed deposits caused by construction activities on the site. 

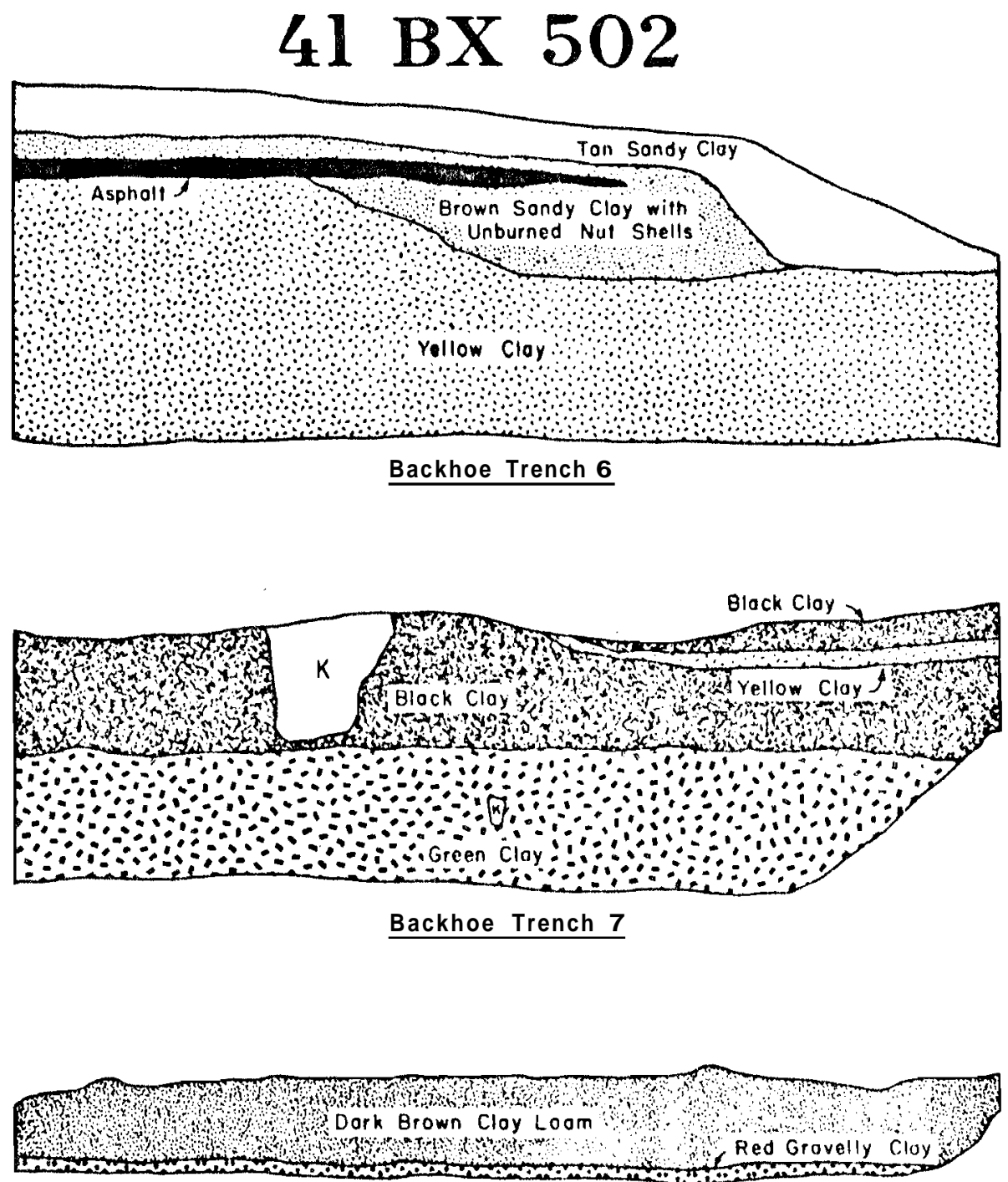

Backhoe Trench 8

(k) Rodent Burrows
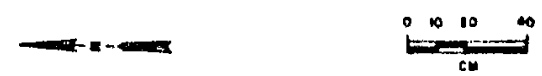

Figure 7. Soil Profiles from Backhoe Trenches 6, 7 and 8 (41 BX 502) 


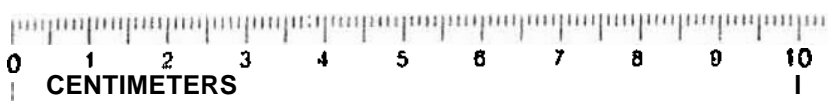
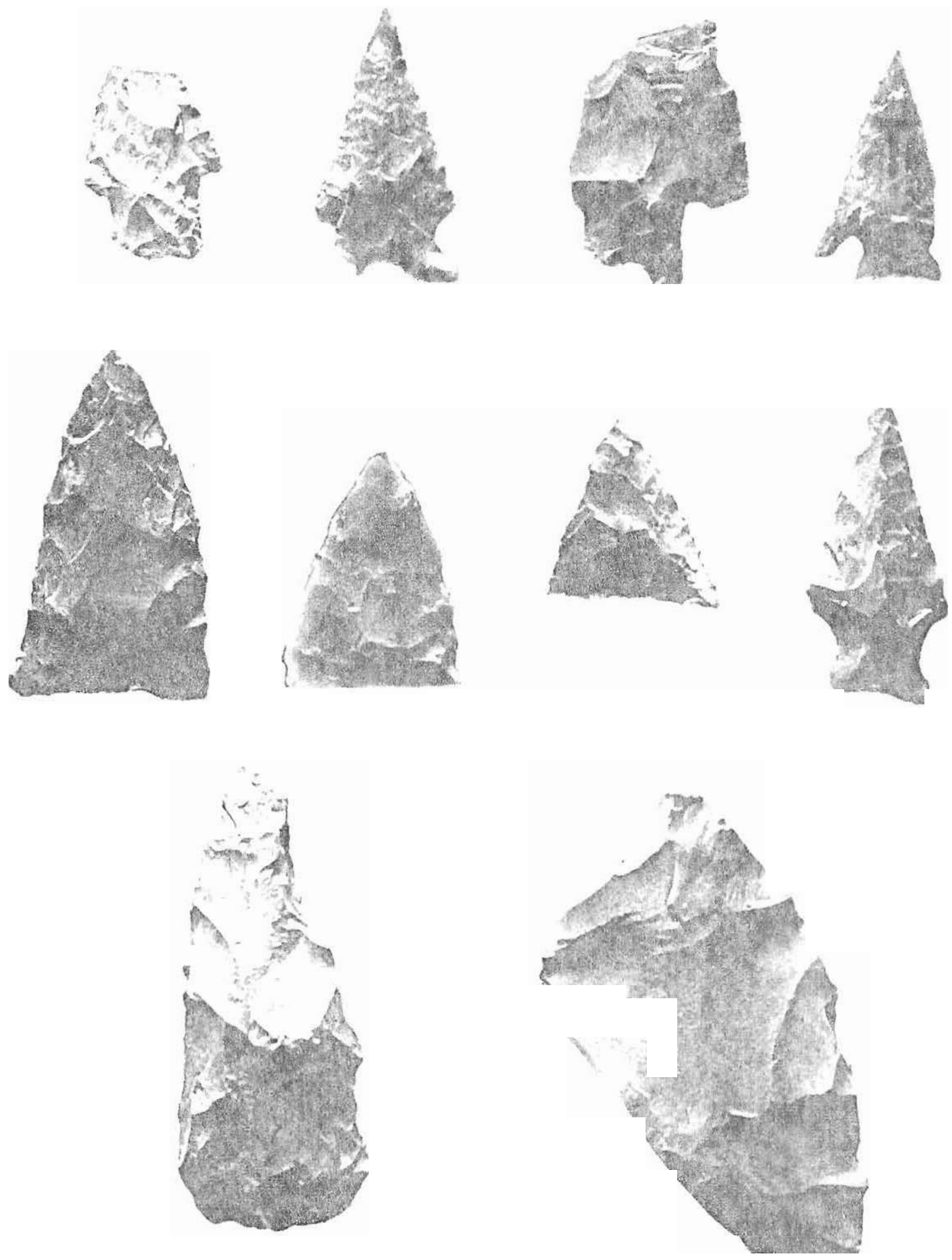

Figure 8. Selected surface artifacts (41 BX 502). 